\title{
EFFECT OF DIFFERENT LITTER TREATMENTS ON PRODUCTION PERFORMANCE OF BROILER CHICKENS
}

\author{
S. Bjedov, D. Žikić, L. Perić, M. Đukić Stojčić, N. Milošević \\ University of Novi Sad, Faculty of Agriculture, Department of Animal Science, Trg Dositeja \\ Obradovića 8, 21000, Novi Sad, Republic of Serbia \\ Corresponding author: sinisa.bjedov@stocarstvo.edu.rs \\ Original scientific paper
}

Abstract: In modern poultry production, foot pad dermatitis (FPD) represents one of the main problems on broiler chicken legs with significant affect on animal welfare and performance. This problem is not solved by the using of straw as litter. Different treatments of straw are needed to eliminate the adverse effects of this material as litter. The most widely used method to improve the quality of litter is chopping straw and application of microbial products on that. These procedures can decrease the moisture in the litter and reduce the population of microorganisms whose activity produces ammonia, and hence improving environmental conditions in facilities. The experiment involved four treatments with four replications with a total of 300 broilers per treatment. The treatment I was unchopped straw, treatment II was chopped straw, treatment III unchopped straw with the addition of microbial products, and treatment IV was chopped straw with the addition of microbial preparation. Duration of trial was 42 days. During the experiment, the following production parameters were measured: body weight per week of the experiment, feed conversion ratio, mortality and FPD. Results of the trial point out that the best production results were in treatment IV with an average final body weight of $2.456 \mathrm{~g}$ and feed conversion ratio of 1.71 .

Key words: foot pad dermatitis (FPD), broiler chickens, microbial preparations, litter, production performance

\section{Introduction}

Foot pad dermatitis (FPD) is a type of contact dermatitis affecting the plantar region of the feet in poultry and other birds. The lesions are commonly named "ammonia burns" and are thought to be caused by a combination of moisture, high ammonia content, and other not yet specified chemical factors in the litter (Berg, 2004). Broiler flocks affected with severe form of footpad dermatitis show leg abnormalities like limping and uncoordinated gait, which negatively 
influences their activity. Birds may also show slower weight gain due to paininduced reduction in feed intake (Bilgilil et al. 2006). Fast growth rate is generally accompanied by decreased locomotory activity and extended time spent sitting or lying. The lack of exercise is considered a main cause of leg weakness, and extreme durations of sitting on poor quality litter produces skin lesions at the breast and the legs. Management factors which slow down early growth alleviate many welfare problems (Bessei, 2006). Locomotor activity is important for the ossification of the bones of growing animals. There is a causal interrelationship between fast growth, low locomotor activity and leg problems. Since growth is a main economical factor, there are problems of acceptability of these measures in the commercial broiler production. Production performance was significantly greater at 42 days of age in birds exposed to lower relative humidity compared with the higher regimen of relative humidity of litter (William et al., 1991).

Both the incidence and severity of ammonia burns on the breast and infected foot pads were significantly higher with 75 versus $45 \% \mathrm{RH}$. Increases in RH significantly increased caking and litter moisture and reduced the percentage of dry matter and the percentage of nitrogen found in the litter.

Hough et al. (1984) indicate that the installation of the product consists of black sulphate, propionic acid, magnesium and copper sulfate in the litter cause significant weight gain without affecting feed conversion and mortality. Also, they found that the product did not significantly affect litter moisture.

Litter serves several functions that include thermal insulation, moisture absorption, protective barrier from the ground, and it allows for natural scratching behavior. Bedding material must not only be a good absorber of moisture but also have a reasonable drying time (Grimes et al., 2002; Bilgili et al., 2009). Although litter refers to the mixture of bedding material, fecal droppings, and moisture, the term is used interchangeably with bedding materials. The most commonly used litter material is straw in Europe (Grimes et al., 2002). Differences in particle size of straw were proposed to be the most important factor. The aim of this study was to determine the effect of litter on the performance of broiler chickens.

\section{Materials and Methods}

The experiment was conducted at the Experimental farm of Faculty of Agriculture in Novi Sad. A total of 1,200 day-old Ross 308 broilers were assigned to four treatments with four replicates. Each replicate consisted of 75 as-hatched birds per pen. Each floor pen measured $5 \mathrm{~m}^{2}$, to give a stocking density of 15 birds $/ \mathrm{m}^{2}$. Air temperature was adjusted in accordance to the technological demands. Lighting program provided 23 hours of light +1 hour of dark. Birds were vaccinated against Newcastle disease (NCD) and infectious bursal disease (IBD) as per commercial recommendations. Feed and water supply were ad 
libitum. The treatment I was unchopped straw, treatment II was chopped straw, treatment III unchopped straw with the addition of microbial products (Micropan ${ }^{\mathrm{R}}$, Eurovix USA ), and treatment IV was chopped straw with the addition of microbial preparation. Duration of trial was 42 days. During the experiment, the following production parameters were measured: body weight per week of the experiment, feed conversion ratio and mortality. These labeled birds were examined weekly for the presence of foot dermatitis and given a lesion score using the methodology described by (Martrenchar et al. 2002). Briefly, the scores were 0: no lesion; 1: lesion on $<25 \%$ of the pads; 2 : lesion on 25 to $50 \%$ of the pads; 3 : lesion on $>50 \%$ of the pads. Data were analyzed by ANOVA using the GLM procedure and means separated by Duncan post hoc test using StatSoft computer package (STATISTICA 11, 2012).

\section{Results and Discussion}

In this paper, the results indicating that the decrease in litter moisture significantly affects the increase of body weight in the final fattening of chickens (Table 1). The results are consistent with the results reached by Harn and Ellen (2009), which suggest that the reduction of the moisture content of the litter was a statistically significant increase in body weight and average daily gain in the fattening of broiler chickens.

Table 1. Production results reflected the proportional share of the lesion

\begin{tabular}{|l|c|c|c|c|}
\hline Parameters/treatment & $\begin{array}{c}\text { Unchoped } \\
\text { straw }\end{array}$ & $\begin{array}{c}\text { Unchoped } \\
\text { straw + MP }\end{array}$ & $\begin{array}{c}\text { Chopped } \\
\text { straw }\end{array}$ & $\begin{array}{c}\text { Chopped } \\
\text { straw }+ \text { MP }\end{array}$ \\
\hline Body weight (g) & $2,358.00^{\text {ab }}$ & $2,322.00^{\mathrm{b}}$ & $2,381.00^{\mathrm{ab}}$ & $2,456.00^{\mathrm{a}}$ \\
\hline Body weight gain (g/b/d) & 56.15 & 55.29 & 56.70 & 58.48 \\
\hline Mortality (\%) & 2.03 & 1.52 & 1.10 & 1.50 \\
\hline FCR & 1.72 & 1.70 & 1.66 & 1.71 \\
\hline EPEF (PI) & 320 & 321 & 338 & 337 \\
\hline
\end{tabular}

\begin{tabular}{|l|c|c|c|c|}
\hline Dry matter litter (\%) & 51.56 & 51.04 & 52.56 & 48.27 \\
\hline Footpad lesions & $(\%)$ & $(\%)$ & $(\%)$ & $(\%)$ \\
\hline 0 & 2.69 & 8.68 & 1.50 & 14.44 \\
\hline 1 & 30.65 & 39.27 & 32.50 & 42.78 \\
\hline 2 & 30.64 & 31.96 & 33.00 & 26.11 \\
\hline 3 & 36.02 & 20.09 & 33.00 & 16.67 \\
\hline
\end{tabular}

$\left({ }^{\mathrm{a}, \mathrm{b}}\right)$ values in the table are statistically significant $(\mathrm{p}<0,01)$

By reducing the moisture in the ground cover can lead to decrease the occurrence and intensity of lesions. This results in a reduction in mortality, conversion and increase production indices in fattening of broiler chickens. A significant increase in the number of chicks without lesions (Harn and Jong, 2012) 
come using acidifiers in the drinking water of broiler chickens. The results reached by De Baere and Zoons (2004) shows that the use of large quantities of chopped straw of $1.5 \mathrm{~kg} / \mathrm{m} 2$, a significant increase in the intensity of the FPD in broiler chickens. In their work, they state that the use of chopped straw at a rate of 2.0 $\mathrm{kg} / \mathrm{m} 2$ leads to a much larger increase in the number of lesions greatest degree of damage.

\title{
Conclusion
}

The emergence of the FPD is multifactorial problem that is influenced by a large number of factors the most significant ventilation, feeding, watering, microclimate and health status of animals. Consequences of the development are significant both in terms of animal welfare and in terms of economic feasibility of production. While reducing litter moisture was not significant it certainly contributed to a significant increase in body mass of chickens for fattening, reducing mortality and increasing conversion and production index in broiler chickens. Good knowledge of all factors can be occurrence of FPD significantly contribute to the prevention of these types of dermatitis and reduced intensity damage in flocks where the disease has occurred.

\section{Acknowledgements}

This work has been funded by the Ministry of Education, Science and Technology Development Republic of Serbia as a part of the Project No. TR 31033.

\section{Efekat različitih tretmana prostirke na proizvodne rezultate brojlerskih pilića}

\author{
S. Bjedov, D. Žikić, L. Perić, M. Đukić Stojčić, N. Milošević
}

\section{Rezime}

U savremenoj živinarskoj proizvodnji jedan od vodećih problema u tovu brojlerskih pilića jesu pododermatitisi. Upotrebom slame kao prostirke ovaj problem se ne rešava. Potrebni su različiti tretmani slame kao bi se negativni efekti ovog materijala, kao prostirke, eliminisali. Najčešće primenjivan način poboljšanja kvaliteta prostirke kod nas je seckanjem slame i aplikacijom mikrobioloških preparata po prostirci. Ovim postupcima je moguće sniženje vlage u prostirci i smanjenje populacije mikroorganizama čijom aktivnošću se stvara amonijak, a 
samim tim se popravljaju i ambijentalni uslovi u objektima. U ogledu su bila uključena četiri tretmana sa po četiri ponavljanja sa ukupno 300 plilića po tretmanu. Tretmani su se sastojali od seckane i neseckane slame sa i bez dodatka mikrobiološkog preparata. Ogled je trajao 42 dana. U ogledu su praćeni sledeći proizvodni parametri: telesne mase po nedeljama tova, konverzija i mortalitet. Tretman I je činila neseckana slama, tretman II seckana slama, tretman III neseckana slama sa dodatkom mikrobiološkog preparata, a tretman IV seckana slama sa dodatkom mikrobiološkog preparata. Po završetku ogleda najbolje proizvodne rezultate je ostvario tretman IV sa prosečnom završnom telesnom masom od 2.456g i konverzijom 1,71.

\section{References}

DE BAERE, K., ZOONS, J. (2004): Strooisel bij vleeskukens hoveelheid houkrullen en stro. Plumivee nr. 39.

BERG, C. (1998): Footpad dermatitis in broilers and turkeys — prevalence, risk factors and prevention. PhD Thesis, Swedish Univ. Agric. Sci., Uppsala, Sweden. Acta Univ. Agric. Suecia,Vet. 36.

BERG, C. (2004): Pododermatitis and hock burn in broiler chickens. Pages 37-49 in Measuring and Auditing Broiler Welfare. C. A. Weeks and A. Butterworth, ed. CABI Publishing, Wallingford, UK.

BESSEI, W. (2006): Welfare of broilers: a review. World Poultry Sci J 62 (03): 455-466.

BILGILI, S. F., ALLEY, M. A., HESS, J. B. NAGARAJ, M. (2006): Influence of age and sex on foot pad quality and yield in broiler chickens reared on low and high density diets. J. Appl. Poult. Res. 15(3): 433-441.

BILGILI, S. F., HESS, J. B., BLAKE, J. P., MACKLIN, K. S., SAENMAHAYAK, B., SIBLEY, J. L.( 2009): Influence of bedding material on footpad dermatitis in broiler chickens. J. Appl. Poult. Res. 18:583-589.

BRUCE, D. W., MCILROY, S. G., GOODALL, E. A. (1990): Epidemiology of a contact-dermatitis of broilers. Avian Pathol. 19:523-537.

EKSTRAND, C., ALGERS, B., SVEDBERG, J. (1997): Rearing conditions and foot pad dermatitis in Swedish broiler chickens. Prev. Vet. Med. 31:167-174.

GREENE, J. A., McCRACKEN, R. M., EVANS, R. T. (1985): A contact dermatitis of broilers - Clinical and pathological findings. Avian Pathol. 14:23-38. GRIMES, J. L., SMITH, J., WILLIAMS, C. M. (2002): Some alternative litter materials used for growing broilers and turkeys. World's Poult. Sci. J. 58:515-526. HARMS, R. H., and SIMPSON, C. F. (1975): Biotin deficiency as a possible cause of swelling and ulceration of foot pads. Poult. Sci. 54:1711-1713.

HARN, van J., ELLEN, H.H. (2009): Gebruik van vloerverwarming bij vleeskuikens. ASG Rapport 171. 
HARN, van J., en JONG, de I. (2012): Zuur is zoet voor zolen (2). Pluimveehouderij 42/7. 1 juni 2012. P. 3031.

HESTER, P. Y. (1994): The role of environment and management on leg abnormalities in meat-type fowl. Poult. Sci. 73:904-915.

HUFF, W. E., MALONE, G. W., CHALOUPKA, G. W. (1984): Effect of litter treatment on broiler performance and certain litter quality parameters. Poult. Sci. 63(11): 2167-2171.

KESTIN, S. C., GORDON, S., SU, G., SORENSEN, P. (2001): Relationship in broiler between lameness, live weight, growth rate and age. Vet. Rec. 148:195197.

MARTRENCHAR, A., BOILLETOT, E., HUONNIC, D. POL, F. (2002): Risk factors for foot pad dermatitis in chicken and turkey broilers in France. Prev. Vet. Med. 52:213-226.

MARTLAND, M. F. (1985): Ulcerative dermatitis in broiler chickens: The effects of wet litter. Avian Pathol. 14:353-364.

McFERRAN, J. B., McNULTY, M. S., McCRACKEN, R. M., GREENE, J. A. (1983): Enteritis and associated problems. Pages 129-138 in Proc. International Union of Immunological Societies: Disease Prevention and Control in Poultry Production. No. 66. University of Sydney, Australia.

MELUZZI, A., FABBRI, C., FOLEGATTI, E., SIRRI, F. (2008): Survey of chicken rearing conditions in Italy: Effects of litter quality and stocking density on productivity, foot dermatitis and carcass injuries. Br. Poult. Sci. 49:257-264.

WILLIAM, D., WEAVER, JR. MEIJERHOF R. (1991): The Effect of Different Levels of Relative Humidity and Air Movement on Litter Conditions, Ammonia Levels, Growth, and Carcass Quality for Broiler Chickens. Poult. Sci. 70 (4): $746-$ 755.

Received 10 September 2013; accepted for publication 15 December 2013 